\title{
Leukocytoclastic vasculitis in a patient with metastatic synovial sarcoma: A case report and review of the literatüre
}

\section{Metastatik sinovyal sarkomlu hastada lökositoklastik vaskülit: Olgu sunumu ve literatürün gözden geçirilmesi}

\author{
Arife Ulaş ${ }^{1}$, İlyas Ferid Kanat ${ }^{2}$, Burak Bilgin ${ }^{3}$, Aylin Yazgan ${ }^{4}$, Didem Şener Dede ${ }^{3}$, Mehmet Ali Nahid \\ Şendur ${ }^{3}$, Muhammed Bülent Akınc1 ${ }^{3}$, Bülent Yalçın ${ }^{3}$ \\ ${ }^{1}$ Ankara Atatürk Eğitim Ve Araştırma Hastanesi, Tıbbı Onkoloji Kliniği, Ankara, Türkiye \\ ${ }^{2}$ Yıldırım Beyazıt Üniversitesi, Tıp Fakültesi, Ankara Atatürk Eğitim Ve Araştırma Hastanesi, \\ İç Hastalıkları Kliniği, Ankara, Türkiye \\ ${ }^{3}$ Yıldırım Beyazıt Üniversitesi, Ankara Atatürk Eğitim Ve Araştırma Hastanesi, Tıbbı Onkoloji Kliniğgi, \\ Ankara, Türkiye \\ ${ }^{4}$ Ankara Atatürk Eğitim Ve Araştırma Hastanesi, Patoloji Kliniği, Ankara, Türkiye
}

\section{ÖZET}

Biz, akciğer metastazı olan sinovyal sarkomlu, yüksek doz ifosfamid tedavisi sonrası lökositoklastik vaskülit gelişen bir olguyu tanımladık. Kırk iki yaşında erkek hasta, sol kol ön-iç kısımda gelişen kitle nedeniyle başvurdu. Operasyon sonrası yüksek gradlı sinovyal sarkom tanısıyla adjuvan tedavilerini aldı. Tedavi bitiminden 10 ay sonra, çok sayıda akciğer metastatik nodülleri nedeniyle yüksek doz ifosfamide tedavisi başlandı. Kemoterapiyi takiben 1 hafta sonra hastada karın ağrısı, kanlı idrar ve her iki alt ekstremitede eritematöz lezyonlar ve palpable purpura gelişti. Hastanın otoantikorları negatif (antikardiyolipin IgG/M, antifosfolipid IgG/M, anti dsDNA, ANA, pANCA ve cANCA), RF normal, C3 ve C4 normal sinırlarda saptandi. Deriden yapılan tam kat deri biopsisi lökositoklastik vaskülit ile uyumlu geldi. $1 \mathrm{mg} / \mathrm{kg}$ prednizolon tedavisi sonrasında hastanın döküntüleri, kanlı idrar ve karın ağrısı tamamıyla geriledi. İlaca bağlı olumsuz ilaç etkisi ihtimalini öngören Naranjo skalasına göre vaskülit ile ifosfamid arasında olası bir ilişki olabileceğini saptadık. Güncel bilgiler ışığında literatürde ifosfamid sonrası lökositoklastik vaskülit gelişen olguya rastlamadık. Biz, burada, yüksek doz ifosfamid alan hastalarda nadir ve olağan dışı bir durum olan lökositoklastik vaskülit gelişebileceğini vurgulamak istedik.

Anahtar Kelimeler: İfosfamid, lökositoklastik vaskülit, ilaca bağlı vaskülit, paraneoplastik vaskülit

\begin{abstract}
We described a case that synovial sarcoma with lung metastasis, presenting with leukocytoclastic vasculitis after treatment with high dose ifosfamide. Forty-two years old male patient was admitted to the hospital due to anteromedial mass on his left arm. He was operated with the diagnosis of high grade synovial sarcoma and he received adjuvant treatment. 10 months later after the end of the therapy, numerous metastatic lung nodules developed and started high dose ifosfamide treatment. Stomachache, hematuria, erythematous lesions, palpable purpura on his bilateral lower extremities developed after 1weeks later of the starting chemotherapy. His autoantibodies were negative (anticardiolipin IG G/M, antiphospholipid Ig G/ M, antids DNA, ANA, pANCA, cANCA) and RF, C3, C4 were normal. Full-thickness skin biopsy resulted as leukocytoclastic vasculitis. After treatment $1 \mathrm{mg} / \mathrm{kg}$ prednisolone, patient's rash, hematuria, abdominal pain disappeared completely. We found that a possible relationship between ifosfamide and vasculitis according to Naranjo scale which envisioning the possibility of drug induced adverse drug effects. In the light of current knowledge, we found no cases developing leukocytoclastic vasculitis after ifosfamide treatment in the literature. Here, we wanted to emphasize that in patients treated with high dose ifosfamide might develop leukocytoclastic vasculitis, which is rare and unusual case.
\end{abstract}

Keywords: Ifosfamide, leukocytoclastic vasculitis, drug -induced vasculitis, paraneoplastic vasculitis 


\section{Giriş}

Lökositoklastik vaskülit (LV), küçük kutanöz damarları etkileyerek, damar duvarında immün kompleks depolanmasina bağlı inflamatuar değişiklikler ve nekrozla karakterize, cilt lezyonlarına neden olan vaskülittir. Damar duvarındaki inflamasyon sonucunda, damar bütünlüğü ve kan akımı bozulur, bunun sonucunda doku iskemisi, organ ve sistemlerde hasarlanmalara yol açar. Klinik pratikte en sik karşılaşılan şekli, kutanöz lökositoklastik vaskülittir. Kutanöz LV, palpable purpura olarak derinin tutulumuyla karakterize bir küçük damar vaskülitidir (1). Küçük damar vaskülitinde, histolojik olarak postkapiller venüllerde nötrofillerden zengin eksuda, endotel hasarı, fibrin birikmesi ve çekirdek kırıntıları bulunur. Lökositoklastik vaskülitin mekanizması altta yatan hastalı̆̆a bağlı olarak değişebildiği gibi, patogenezinden immünkompleksler sorumlu tutulmaktadır (2).

Küçük damar vaskülitlerinin belirti ve bulguları değişkendir. Kısa süren kutanöz erüpsiyondan, yaşamı tehdit eden iyi seyirli tablodan, çoklu organ yetmezliğine kadar ilerleyen şiddetli formları içeren geniş bir yelpazede olabilir. Sistemik bulgular, siklıkla ateş, artralji, artrit, daha az yaygın olarak böbrek, nörolojik ve gastrointestinal tutulumla karakterizedir $(3,4)$.

Kutanöz vaskülitin etyolojik nedenleri arasında idiopatik \%45-55, enfeksiyonlar \%15-20, inflamatuar hastalıklar \%15-20, ilaç ve maligniteler \%5-15 oranında saptanmıştır. Vaskülit, hematolojik malignitelerle daha çok ilişkili olup solid malignitelerle birlikteliği nadirdir. Solid malignitelerden prostat, meme, kolon, böbrek hücreli kanser ve akciğer kanserlerinde vaskülit bildirilmiştir $(4,5)$. İlaca bağlı vaskülitli (IBV) hastaların \%63'ünü kutanöz vaskülit oluşturur. Bu olguların çoğu, hipersensitivite vasküliti olarak ortaya çıar ve yüzeyel, dermal, küçük damar nötrofilik vaskülit olarak görülür (5). Çok ileri tetkikler kullanılsa bile etyolojik ajanın kesin olarak belirlenmesinin güç olduğu bilinmelidir.

Biz, burada, metastatik sinovyal sarkom tanısıyla yüksek doz ifosfamid kemoterapisi sonrası lökositoklastik vaskülit gelişen olguyu bildirmeyi amaçladık.

\section{Olgu Sunumu}

Kırk iki yaşında, bilinen sistemik hastalığ olmayan, ailesinde meme ve akciğer kanseri öyküsü bulunan erkek hasta Şubat 2013'te sol kolda ağr1 ve kitle nedeniyle bir onkoloji merkezine başvurmuş. Yapılan fizik muayenesinde sol kol ön-orta kesimde yaklaşık 10x10 cm. boyutlarında ele gelen kitle saptanmış. Üst ekstremite manyetik rezonans (MR) görüntülemede humerus anteromedial komşuluğunda, kortexte belirgin destrüksiyona yol açmayan, kas planlarına invaze, yaklaşık 10x10x17 cm boyutlarında, kontrast madde tutulumu gösteren sol aksiller arter ve ven ile yakın komşuluk gösteren, aksillaya doğru uzanımı izlenen kitle lezyonu izlenmiştir. Yapılan insizyonel biyopsi patolojisi; yüksek gradlı, sinovyal sarkomla uyumlu gelmiş. Uzak metastazı olmayan hastada Nisan 2013'te kitle rezeksiyonu yapılmış. Patolojisi monofazik sinovyal sarkom, tümör çap1: $15,5 \times 10 \times 8,5 \mathrm{~cm}$, cerrahi sinır temiz olarak raporlanmış. Ardından hastaya radyoterapi tedavisi $(60 \mathrm{~Gy})$ ve adjuvan 3 kür IMA (ifosfamid $1800 \mathrm{mg} / \mathrm{m}^{2}$ 1-5. günler, mesna $1800 \mathrm{mg} / \mathrm{m}^{2} 1-5$. günler, doksorubisin $25 \mathrm{mg} / \mathrm{m}^{2} /$ gün 1 -3. günler, 21 günde bir ) uygulanmış. Kemoterapi bitiminden 10 ay sonra yapılan toraks bilgisayarlı tomografide (BT) her 2 akciğerde en büyüğü sağ akciğer alt lopta $15 \mathrm{~mm}$ olmak üzere çok sayıda metastatik nodüller saptanmış. $\mathrm{Bu}$ dönemde hasta takip edildiği merkezden ayrılarak bizim kliniğimize başvurdu. Göğ̈̈ cerrahisi ile tekrar değerlendirilen hastanın lezyonlarının cerrahiye uygun olmadığına karar verildi. Hastaya metastatik sinovyal sarkom, akciğer metastazı tanısıyla yüksek doz ifosfamid kemoterapisi (ifosfamid $2 \mathrm{gr} / \mathrm{m}^{2} / \mathrm{gün}, \quad 1$ 7.günler, mesna $2 \mathrm{gr} / \mathrm{m}^{2} /$ gün, 1-7. günler, 21 günde bir ve 8 . günden itibaren 7 gün boyunca koruyucu granülosit koloni uyarıcı faktör (GCSF 48 Mü) uygulaması planlandı. İkinci kür kemoterapiyi takiben 1 hafta sonra karın ağrısı, kanlı idrar, her iki alt ekstremitede ve ayaklarda eritemli, palpable purpura şeklinde döküntülerle servise yatırıldı (Resim 1). Romatoloji bölümü ile birlikte değerlendirildi. $\mathrm{Bu}$ klinik tablonun öncelikle kemoterapiye ikincil olabileceği düşünüldü. Yapılan tetkiklerde; antikardiyolipin $\mathrm{IgG} / \mathrm{M}$, antifosfolipid $\mathrm{IgG} / \mathrm{M}$, anti dsDNA, ANA, antinötrofil sitoplazmik antikorlar (pANCA ve cANCA), RF normal, C3 ve C4 normal sinirlarda saptandi. Hemogram ve 
biyokimyasal değerleri normal sınırlarda idi. Sedimantasyon $70 \mathrm{~mm} / \mathrm{saat}$ idi. İdrar tetkiklerinde mikroskobik kanlı idrar saptand1, proteinüri yoktu. Yapılan tetkiklerde kanlı idrarı açıklayacak ilaç dışında bir neden saptanmadi. Gaitada gizli kan iki kez pozitif ve bir kez negatif geldi. Üst gastrointestinal endoskopisinde mide antrum kısmı ödemli ve benekli tarzda hiperemikti. Batın ultrasonografisi normal idi. Deriden yapilan tam kat deri biopsisinde üst dermiş ve orta dermiste küçük çaplı damar çevrelerini ve damar duvarını atake eden nötrofiller, eozinofiller, lökositler ve fibrinoid nekroz saptand1. Deri biopsisi lökositoklastik vaskülit olarak raporlandı (Resim 2). Hastaya $1 \mathrm{mg} / \mathrm{kg}$ prednizolon tedavisi başland. Takiplerinde prednizolon dozu azaltılan hastanın döküntüleri tamamıyla kayboldu. İki kür kemoterapi sonrası yapılan toraks BT'de kısmi yanıtla uyumlu bulgular saptanması üzerine tedavi tamamiyle kesildi. İlaç yan etkileri Naranjo'nun ilaç yan etki olasıllığı ölçeği

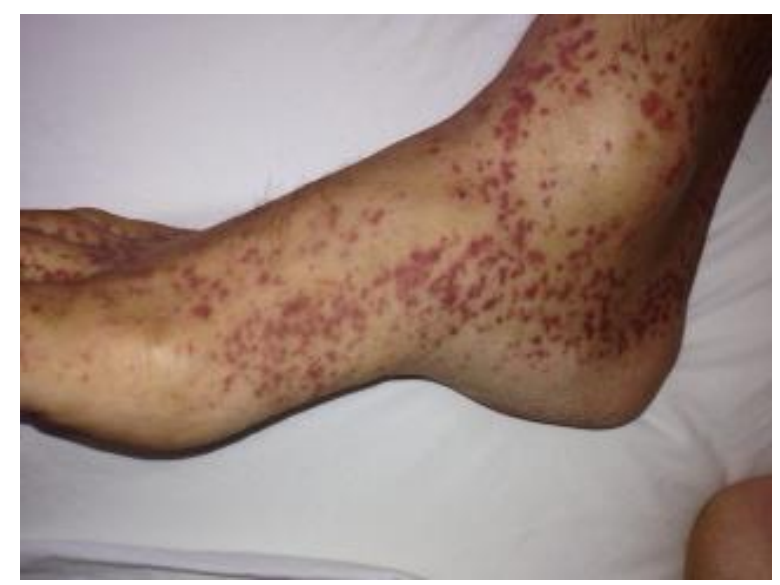

Resim 1: Lökositoklastik vaskülitli olguda alt ekstremitede sağ ayaktaki peteşiyel lezyonlar ve palpable purpuralar

\section{Tartışma}

Lökositoklastik vaskülit terimi ilk olarak 1950 yılında ilaç alımı sonrasında küçük damarlarda oluşan hipersensitivite vasküliti olarak adlandırılmıştır (7). Kutanöz vaskülit (KV), nekrotizan vaskülit veya lökositoklastik vaskülit olarak adlandırılan klinik tablo, palpable purpura, nekroz, ülser, nodül, ürtiker, livedo retikülaris gibi çeşitli deri lezyonlarıyla
(Adverse drug reaction probability scale) ile değerlendirildi. $\mathrm{Bu}$ ölçeğe göre 9 ve üzeri puan kesin, 5-8 puan arası kuvvetle muhtemel, 1-4 puan arası olası, 0 puan şüpheli olarak değerlendirilmektedir (6). Vakamız bu ölçeğe göre toplam 4 puan aldı. İlaca bağlı olumsuz ilaç etkisinin başka faktörlerden ziyade ne derecede ilaca bağlı olduğu ihtimalini öngören Naranjo skalasına göre olası bir ilişki olduğunu saptadık. Tedavisiz 5 aylık aradan sonra yapılan görüntülemelerinde her iki akciğerde metastatik nodüllerde sayı ve boyut artış1 olması nedeniyle hastaya tekrar yüksek doz ifosfamid tedavisi başlanıldı. 3 kür sonrası yapılan yanıt değerlendirmesinde kısmi gerileme saptandi. Toplam 6 kür verildi. $\mathrm{Bu}$ dönemde vaskülit tablosu tekrarlamadı. $\mathrm{Bu}$ ikinci kez verilen ifosfamid tedavisi bitiminden 3 ay sonra akciğer metastazlarında tekrar ilerleme saptanan hastaya Pazopanib tedavisi başlanıldı. Hastanın takipleri halen devam etmektedir.

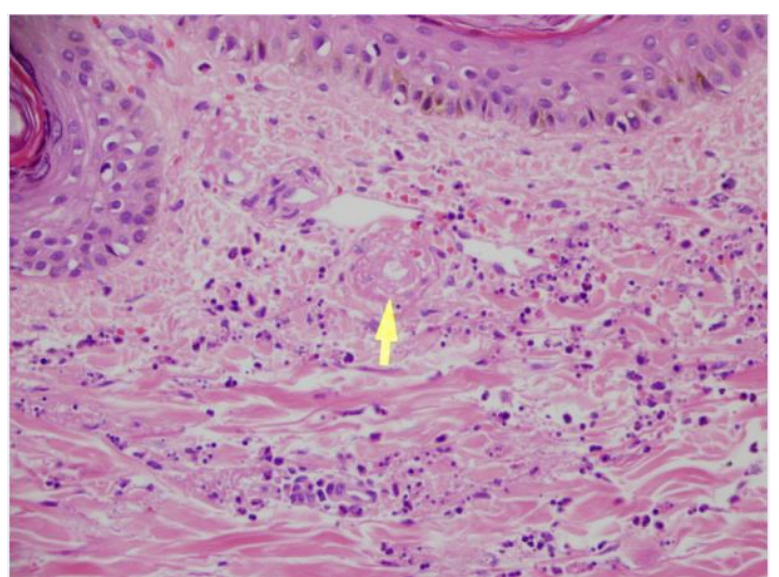

Resim 2: Olgunun deri biyopsisinde üst dermiste damar duvarında fibrinoid nekroz (ok) ve çevresinde lökositoklastazis (Hematoksilen eozin x40)

ortaya çıkar. Deride sınırlı olabileceği gibi birçok organı da tutabilir (8).

Lökositoklastik vaskülit çoğunlukla idiopatik olmakla birlikte enfeksiyon, ilaçlar, inflamatuar hastalıklar ve travma gibi faktörlere ikincil olarakta gelişebilir (8). LV etyolojisinde bazı risk faktörleri üzerinde durulmakta ve her geçen gün LV ile ilgili yeni risk faktörleri literatüre girmektedir (9). Yaklaşık olarak kutanöz vaskülitlerin \%20'si bir ilaç erüpsiyonu sonucunda ortaya çıkar. 
İlaca bağlı vaskülitli (İBV) hastaların \%63'ü kutanöz vaskülit tablosuyla başvururlar (10). Çoklu organ tutulumu ortaya çıktığı zaman hastalık yaşamı tehdit edebilir. İBV'te ilaca ilk maruziyet ile semptomların ortaya çıkışı arasındaki aralık oldukça geniş olabilir. İlacın dozundaki artışlara veya ilaca maruziyetten saatler veya yıllar içerisinde ortaya çıkabilir (11). İBV'te kesin patogenetik mekanizmalar bilinmiyor. Hem hücresel hem de humoral immünite önemli rol oynamaktadır. ANCA pozitif IBBV'te, ANCA antijeni damar duvarına nötrofillerin tutunmasinı ve migrasyonunu arttırır. Nötrofillerin proteolitik enzim salınımını ve nihayetinde vaskülit oluşumunu tetikler. Genellikle ANCA pozitifliği (özellikle anti MPO $\mathrm{Ab}$ ) ciddi bir hastalık seyriyle ilişkilidir (12).

Lökositoklastik vaskülite yol açan ilaçlar arasında penisilinler, sülfonamidler, NSAIII, allopürinol, tiyazidler, insülin, retinoidler, kinolon grubu antibiyotikler ve beta laktam grubu antibiyotikler yer almaktadir (13). Antitiroid ilaç tedavisinin Lupus benzeri İBV'e yol açtığı gösterilmiştir. Propiltiourasil veya metimazol tedavisi ile IBV geliştiren Gravesli hastalarda bir genetik yatkınliktan ötürü de gelişmesi muhtemeldir. MPO-ANCA ile tiroglobulin antikor $(\mathrm{Ab})$ düzeyleri arasında pozitif ilişki vardır (14).

Kemoterapötikler arasında kapesitabin, oksaliplatin, gemsitabin, 5-fluoraurasil, folinik asid, tamoksifen, aromataz inhibitörleri ve erlotinible ilgili vaskülit tablosu bildirilmiştir $(15,16,17,18,19,20)$. Tamoksifene bağl1 kutanöz vasküliti içeren deri değişiklikleri, tamoksifen kullanan hastaların yaklaşık \%19'unda bildirilmişti (19). Tamoksifen tedavisinde ilaç tekrar başlandığında vaskülitin tekrar ortaya çıkması ve tedavinin kesilmesinden sonra toksisitenin hızla çözülmesi ilacın tetiklediği etkiyi destekler. Aromataz inhibitörleri, aromataz aktivitesini azaltarak östrojen düzeylerini azaltırlar. Anastrozol tedavisinde de kutanöz vaskülit bildirilmiş olup ilaç tedavisi kesildikten sonra vaskülit bulguları kaybolmuştu (20). EGFR hedefleyen tedavilerde deri toksisitesi, sıklıkla tipik akneiform döküntülerle ve kutanöz vaskülitle karakterizedir (21).

Bizim olgumuz, bilgilerimize göre yüksek doz ifosfamide kemoterapisi sonras1 gelişen ilk lökositoklastik vaskülitli olgu idi. Hastanın klinik tablosu, kemoterapi tedavisi sonrasında ortaya çıkması, eritematöz döküntüler, palpable purpura ve kanlı idrar olması vaskülitten şüphelenmemize yol açtı. Hastamızda otoimmün antikorların hepsi negatif geldi. Deriden yapılan tam kat biopsi lökositoklastik vaskülit tanısını doğruladı. İlaca bağlı olumsuz ilaç etkisinin başka faktörlerden ziyade ne derecede ilaca bağl1 olduğu ihtimalini öngören Naranjo skalasına göre ifosfamid ile vaskülit arasında olası bir ilişki olduğunu saptadık.

Vaskülitlerde çok ileri tetkikler kullanılsa bile etyolojik ajanın kesin olarak belirlenmesinin güç olduğu bilinmelidir. Biz, bu olguda zeminde yatan metastatik, yüksek dereceli sinovyal sarkom olmasının da vaskülit gelişiminde rol oynayabileceğini biliyoruz. Malign hastalıklarla ilişsili kutanöz vaskülit, paraneoplastik vaskülit (PNV) şeklinde de ortaya çıkabilir $(3,4)$. Lökositoklastik PNV'nin etyopatogenezinde malign hücrelerin antijen ürettiği, lenfokinlerin ve diğer vazoaktif maddelerin salınımıla PNV'e neden olduğu ileri sürülür. $\mathrm{Bu}$ konuda ilk kez 1986'da Longley ve arkadaşları tarafından malignite gelişimi esnasında oluşan antijenlerin ikincil vaskülit gelişimine neden olduğu bildirilmişti (22). Malignitelerde PNV, maligniteyle eş zamanlı olabileceği gibi aynı zamanda vaskülit bulguları kanser tanısından 25 ay öncesi ile 9 ay sonrasında ortaya çıkabilir $(3,4)$.

Genellikle, PNV semptom ve bulguları altta yatan kanserden muzdarip olan hastalardakine benzer. Kilo kaybi, genel sağlikta azalma, deri purpurasının seyrinde kronik relapslar görülebilir. Bazen LSV'te özel bir laboratuvar bulgusu olmayip sedimentasyon hızında artış, anemi, lenfositoz, eozinofili bulunabilir. Romatoid faktör için pozitif test veya kompleman düzeyinde azalma saptanabilir $(3,4,5)$. PNP vaskülitin prognozu, öncelikle altta yatan hastalığın etkili tedavisine bağlıdır. Malignitenin tedavisi, sıklıkla kutanöz lezyonların gerilemesiyle sonuçlanır. Kemoterapi kürleri arasinda semptomlar tekrarlayabilir $(3,4,5)$. Bizim hastamızda vaskülitin kürler arasında tekrarlamaması, daha önceki tedaviler sırasında ve ilaçsız dönemlerde görülmemesi ve kemoterapi tedavisi kesildikten sonra vaskülitin gerilemesi bizi kısmen PNV'ten uzaklaştırabilir. Ancak, yine de paraneoplastik vaskülit ile İBV arasında kesin ayırım yapmak mümkün olmayabilir. 
Lökositoklastik vaskülitte, tedavi etyolojik nedenin belirlenmesiyle başlar. Kutanöz LSV'ün prognozu iyidir ve çoğunlukla kendi kendini sınırlayan tek bir atak şeklinde görülür. Vaskülite yol açan ilacın kesilmesi, genellikle klinik bulguların iyileşmesine yol açtığı için daha fazla tedaviye ihtiyaç olmaz. Bununla birlikte, bazı hastalarda tetikleyen ilaç kesilse bile ciddi ve yaşamı tehdit eden vaskülit bulguları ilerlemeye devam eder. Sistemik steroid tedavisi (0.5-1 $\mathrm{mg} / \mathrm{kg} /$ gün başlangıç dozu) kutanöz LSV için en yaygın kullanılan ilaçtır. Siklofosfamid, intravenöz immünglobulin $\mathrm{G}$, plazmaferez ve hemodiyaliz tedaviye dirençli olgularda önerilen tedavi seçenekleridir. Vakaların yaklaşı $\% 10$ 'unda ölüm ortaya çıkabilir ve s1klıkla çoklu organ tutulumu olan hastalarda görülür $(10,11,23)$. Bizim olgumuzda, vaskülitin deriye sınırlı olduğu, erken tanı ve hemen ardından başlanılan steroid tedavisi ile etkin bir şekilde tedavi edildiği görülmüştür.

Sonuç olarak; lökositoklastik vaskülit, etyolojisinde çeşitli faktörlerin sorumlu tutulduğu bir klinik tablodur. Bu, bizim bilgimize göre yüksek doz ifosfamid kemoterapisi sonrası gelişen ilk lökositoklastik vaskülit olgusudur. Kemoterapiyi takiben gelişen kanlı idrar, karın ağrısı ve palpable purpura özellikle ilaca bağlı vaskülit tanısından şüphelenmemizi sağlar. Kemoterapilerin nadir görülen yan etkilerinin bilinmesi, bunların erken $\tan 1$ ve tedavilerinin yapılmasinın hastanın yaşam kalitesi üzerinde önemli etkiye sahip olduğunun bilinmesi faydalı olacaktır. Biz burada, lökositoklastik vaskülitin malign hastalığın seyri sırasında görülebileceği gibi yüksek doz ifosfamid tedavisi sonrasında da gelişebileceğini vurgulamak istedik.

\section{Çıkar Çatışması: Belirtilmedi}

\section{Kaynaklar:}

1. Hautmann G, Companile G, Lotti Mt. The many foces of Cutoneous Vasculitis. Clin Dermatol 1999; 17: 515-531

2. Ghersetich I, Comacchi C, Katsambas A, et al. Cellular steps in pathogenesis of cutaneous necrotizing vasculitis. Clin Dermatol 1999; 17: 597601.

3. Gonzalez-Gay MA, Garcia-Porrua C, Salvarani C, Hunder GG. Cutaneous vasculitis and cancer: a clinical approach. Clin. Exp. Rheumatol 2000; 18(3): 305-307
4. Kurzrock R, Cohen P, Markowitz A. Clinical manifestations of vasculitis in patients with solid tumors. A case report and review of the literature. Arch Intern Medical 1994; 154 (3): 334-340

5. Carlson JA, Ng BT, Chen KR. Cutaneous vasculitis update: diagnostic criteria, classification, epidemiology, etiology, pathogenesis, evaluation and prognosis, Am. J. Dermatopathol 2005; 27(6): 504-28

6. Naranjio CA, Busto U, sellers EM et al. A method for estimating the propability of advers drug reactions (Naranjo ADR probability scale). Clin Pharmacol Ther 1981; 30: 239-45

7. Chung L, Kea B, Fiorentino DF. Cutaneous Vasculitis. In: Bolognia JL, Jorizzo JL, Rapini RP, editors. Dermatology. 2st ed. St Louis: Mosby; 2008. p.347-67

8. Blanco R, Martínez-Taboada VM, RodríguezValverde V, etal. Cutaneous vasculitis in children and adults. Associated diseases and etiologic factors in 303 patients. Medicine 1998; 77: 403-18

9. Carlson J, Ng BT, Chen KR. Cutaneous vasculitis update: diagnostic criteria, classification, epidemiology, etiology, pathogenesis, evaluation and prognosis. Am. J. Dermatopathol 2005; 27 (6) : 504528

10. Ten Holder SM, Joy MS, Falk RJ. Cutaneous and systemic manifestations of drug-induced vasculitis. Ann Pharmacother 2002; 36 (1): 130-147

11. Wiik A. Drug-induced vasculitis. Curr Opin Rheumatol 2008; 20 (1): 35-39

12. Choi HK, Merkel PA, Walker AM, Niles JL H. Drug-associated antineutrophil cytoplasmic antibodypositive vasculitis: prevalence among patients with high titers of antimyeloperoxidase antibodies. Arthritis Rheum 2000; 43 (2): 405-413

13. Mullick FG, McAllister HA Jr, Wagner BM, Fenoglio JJ Jr. Drug related vasculitis. Clinicopathologic correlations in 30 patients. Hum Pathol 1979;10(3):313

14. Herlin T, Birkebaek NH, Wolthers OD, Heegaard $\mathrm{NH}$, Wiik A. Anti-neutrophil cytoplasmic autoantibody (ANCA) profiles in propylthiouracilinduced lupus-like manifestations in monozygotic triplets with hyperthyroidism. Scand J Rheumatol 2002; 31(1): 46-9

15. Al-Shamsi HO, Kee BK, Tetzlaff MT, Wolff RA. Capecitabine-induced leukocytoclastic vasculitis under neoadjuvant chemotherapy for locally advanced colorectal cancer. J Gastrointest Oncol 2015; 6(3): 40-3

16. Quack H, Erpenbeck L, Wolff HA, et al. OxaliplatinInduced Leukocytoclastic Vasculitis under Adjuvant Chemotherapy for Colorectal Cancer: Two Cases of a Rare Adverse Event. Case Rep Oncol 2013; 6(3): 609-15

17. Contreras-Steyls M, Lopez-Navarro N, Gallego E, Moyano B, Estrada D, Herrera E. Gemcitabine therapy-associated cutaneous vasculitis with a polyarteritis nodosa-like pattern. Int J Dermatol 2013; 52(8): 1029-31

18. Pellegrini F, Astorino S, Castaldi N, Fassone F, Pasquini P. Small vessel vasculitis related to 5fluorouracil and folinic acid. Eur J Dermatol 2010; 20(6): $862-3$ 
19. Candelaria M, Hurtado-Monroy R, Vargas-Viveros $\mathrm{P}$, et al. Tamoxifen-associated vasculitis in a breast cancer patient. World J Surg Oncol 2007; 5: 9-11

20. Santoro S, Santini M, Pepe C, et al. Aromatase inhibitor-induced skin adverse reactions: exemestanerelated cutaneous vasculitis. J Eur Acad Dermatol Venereol 2011; 25(5): 596-8

21. Brandi G, Venturi M, Dika E,et al. Cutaneous leukocytoclastic vasculitis due to erlotinib: just an adverse event or also a putative marker of drug efficacy? Cutan Ocul Toxicol 2013; 32(4): 336-8

22. Longley S, Caldwell JR, Panush RS. Paraneoplastic vasculitis. Unique syndrome of cutaneous angiitis and arthritis associated with myeloproliferative disorders. Am J Med 1986; 80: 1027-30

23. Russell JP, Gibson LE. Primary cutaneous small vessel vasculitis: approach to diagnosis and treatment. Int J Dermatol 2006; 45: 3-13. 